\title{
ANALISIS PENENTUAN SAHAM PORTOFOLIO OPTIMAL DENGAN MODEL MARKOWITZ PADA PERUSAHAAN SEKTOR PERTAMBANGAN YANG TERDAFTAR DI BURSA EFEK INDONESIA PERIODE JANUARI 2019 - DESEMBER 2020
}

\author{
Bunga Wahyu Ningsih ${ }^{1}$, Muhamad Helmi ${ }^{2}$, dan Debi Carolina ${ }^{3}$ \\ Sekolah Tinggi Ilmu Ekonomi Mulia Darma Pratama \\ e-mail : bungawahyun29@gmail.com ${ }^{1}$,hm.helmi@gmail.com², debbychiby@gmail.com³
}

\begin{abstract}
ABSTRAK
Dalam kegiatan investasinya, pasar modal menawarkan berbagai pilihan berinvestasi dengan tingkat keuntungan (return) dan tingkat risiko (risk) yang berbeda-beda. Untuk mengurangi risiko dalam investasi tersebut maka investor membentuk sebuah portofolio. Portofolio optimal dengan model Markowitz yang dipilih dari sekian banyak alternatif portofolio efisien dapat memberikan tingkat return yang maksimal sesuai dengan risiko yang berani ditanggung oleh investor. Tujuan penelitian ini untuk mengetahui portofolio saham yang optimal serta proporsi dana masing-masing saham dengan menggunakan model Markowitz. Penelitian dilakukan di BEI pada saham perusahaan sektor pertambangan periode Januari 2019-Desember 2020. Data yang digunakan dalam penelitian adalah data sekunder yang diperoleh dari www.idx.co.id dan www.finance.yahoo.com. Jumlah populasi dalam penelitian ini adalah 47 saham perusahaan sector pertambangan yang terdaftar di Bursa Efek Indonesia periode Januari 2019-Desember 2020 dan jumlah sampel sebanyak 11 saham perusahaan, dengan teknik purposive sampling. Hasil penelitian ini menunjukkan bahwa dari 11 saham perusahaan diperoleh sebanyak 4 saham yang masuk dalam portofolio optimal menggunakan model Markowitz dengan jumlah proporsi dananya yakni PT. Harum Energy Tbk (HRUM) sebesar 12,45\%, PT. Timah Tbk (TINS) sebesar 24,42\%, PT. Merdeka Copper Gold Tbk (MDKA) sebesar 53,07\% dan yang terakhir PT. Indika Energy Tbk (INDY) sebesar 10,05\%. Memberikan expected return sebesar 4,70\% dan tingkat risiko sebesar $2,83 \%$.
\end{abstract}

Kata Kunci : Risiko, Return, Portofolio Optimal, Model Markowitz.

\section{ABSTRACT}

The capital market offers a variety of investment opportunities with varying levels of return and risk in its investment activities. Investors create a portfolio to decrease the risk of these assets. The optimal Markowitz model portfolio, chosen from a large number of alternative efficient portfolios, can deliver the highest rate of return based on the risk that investors are willing to take. The goal of this research is to use the Markowitz model to determine the optimal stock portfolio and the proportion of funds for each stock. For the period of January 2019 to December 2020, the analysis was conducted on the IDX on shares of mining sector businesses. Secondary data was gathered from www.idx.co.id and www.finance.yahoo.com for this study. The overall population in this study is 47 shares of mining sector businesses listed on the Indonesia Stock Exchange from January 2019 to December 2020, with 11 company shares being sampled using purposive sampling.The findings of this study show that out of the 11 shares of the company included in the optimal portfolio using the Markowitz model: PT. Harum Energy Tbk (HRUM) with a total proportion of funds of $12.45 \&$, PT. TimahTbk (TINS) with a total proportion of funds of 24.42\%, PT. Merdeka Copper Gold Tbk (MDKA) with a total proportion of funds of 53.07\%, PT. Indika Energy Tbk (INDY) is the last one, with a 10.05\% gain. Provides a risk level of $2.83 \%$ and a projected return of $4.70 \%$.

Keywords: Risk, Return, Optimal Portfolio, Markowitz Model. 


\section{PENDAHULUAN}

Perkembangan pasar modal di Indonesia menunjukkan sebuah indikasi bahwa pasar modal sudah menjadi alternatif sebuah investasi bagi pemilik modal atau investor. Proses perubahan teknologi, ekonomi, industri dan perdagangan selalu berganti seiring dengan perubahan zaman. Sehingga instrumen-instrumen perdagangan dan keuangan semakin beraneka ragam dan bertambah pula. Pada prinsipnya, pasar modal merupakan tempat bertemunya investor yang memilki kelebihan dana dengan manajemen yang membutuhkan dana (Tandelilin, 2010:26).

Dalam setiap investasi saham, selain mengharapkan keuntungan terbesar tentunya selalu ada risiko yang mengikuti. Risiko ini dapat dikurangi dengan melakukan strategi diversifikasi dalam portofolio. Sejalan dengan yang diungkapkan oleh Markowitz (dalam Jogiyanto, 2013:285) menunjukan bahwa untuk mengurangi risiko investasi dalam hal ini maka investor dapat berinvestasi dalam berbagai jenis saham dengan membentuk portofolio. Menurut Hadi (2013:207) portofolio adalah kumpulan suatu instrumen investasi yang dibentuk untuk memenuhi suatu sasaran umum investasi. Sasaran dari suatu portofolio investasi tentunya sangat tergantung dari individu masing-masing investor.Analisis portofolio membantu investor dalam mengambil keputusan untuk menentukan portofolio mana yang paling efisien yang mempunyai tingkat keuntungan yang diharapkan terbesar dengan risiko tertentu atau yang mempunyai risiko terkecil.

$$
\text { Portofolio efisien merupakan }
$$

portofolio yang baik, tetapi bukan yang terbaik (Jogiyanto, 2012:307).Seorang investor akan memilih portofolio sesuai dengan preferensi investor yang bersangkutan terhadap return dan risiko yang akan ditanggungnya. Maka portofolio optimal merupakan portofolio yang dipilih seorang investor dari sekian banyak pilihan portofolio efisien yang ada. Portofolio optimal merupakan portofolio yang dibentuk dengan return harapan dan risiko yang terbaik. Menurut Tandelilin (2010:157) portofolio optimal adalah portofolio yang sesuai dengan preverensi investor dari beberapa pilihan pada portofolio efisien.

Salah satu tujuan para investor dalam melakukan transaksi saham adalah untuk memperoleh return atau imbalan dari investasi yang dilakukan.Return atau tingkat pengembalian saham adalah salah satu faktor yang memotivasi investor berinteraksi dan juga merupakan imbalan atas keberanian investor dalam menanggung risiko atas investasi yang dilakukan (Tandelilin, 2010:102). Selain mengharapkan keuntungan (return) terbesar dalam aktivitas investasi, para investor juga harus mempertimbangkan adanya risiko (risk). Risiko adalah kemungkinan selisih antara return aktual yang diterima dengan return harapan (Tandelilin, 2010:102-103).Secara umum, hampir semua investasi mengandung faktor ketidakpastian atau risiko. Investor tidak yakin apakah mereka akan mendapatkan keuntungan dari investasi yang mereka lakukan.

Menurut Tandelilin (2010:202) terdapat dua cara yang dapat digunakanuntuk mempermudah dalam melakukan diversifikasi (portofolio) yaitu dengan cara diversifikasi random (naif) dan dengan cara Markowitz. Diversifikasi random atau naif terjadi ketika investor menginvestasikan dananya secara acak pada berbagai jenis saham yang berbeda atau pada berbagai jenis aset yang berbeda tanpa memperhatikan return dari sekuritas. Diversifikasi Markowitz mengatasi kelemahan tersebut dengandapat memanfaatkan semua informasi yang tersedia, sehingga dapat dijadikan rujukan untuk membuat sebuah portofolio optimal dengan mempertahankan return yang ada dan meminimalkan risiko melalui analisa kovarians antar return aktiva.

Diversifikasi Markowitz menjadikan pembentukan portofolio menjadi lebihselektif terutama dalam memilih aset- 
aset sehingga diharapkan memberikan manfaat diversifikasi yang paling optimal. Menurut Tandelilin (2010:116) menyatakan bahwa pada model Markowitz meyakini bahwa penambahan saham secara terus menerus pada satu portofolio, pada suatu titik tertentu akan semakin mengurangi manfaat diversifikasi dan justru akan memperbesar tingkat risiko. Model Markowitz mengukur portofolio optimal melalui mean dan variance. Menurut Jogiyanto (2015), metode mean-variance dari Markowitz menunjukkan bahwa sekuritas-sekuritas yang mempunyai korelasi lebih kecil dari +1 akan menurunkan risiko portofolio. Semakin banyak sekuritas yang dibentuk kedalam portofolio, maka semakin kecil risiko portofolio.

Dalam penelitian ini, locus penelitian yang digunakan adalah perusahaan sektor pertambangan yang terdaftar di Bursa Efek Indonesia periode Januari 2019 - Desember 2020. Berdasarkan latar belakang masalah penelitian ini, maka peneliti tertarik untuk meneliti dengan judul "ANALISIS PENENTUAN SAHAM PORTOFOLIO OPTIMAL DENGAN MODEL MARKOWITZ PADA PERUSAHAAN SEKTOR PERTAMBANGAN YANG TERDAFTAR DI BURSA EFEK INDONESIA PERIODE JANUARI 2019 DESEMBER 2020”.

Adapun rumusan masalah dalam penelitian ini adalah :

1. Manakah saham-saham yang membentuk portofolio optimal dengan model Markowitz pada perusahaan sektor pertambangan yang terdaftar di Bursa Efek Indonesia periode Januari 2019Desember 2020?

2. Berapakah proporsi dana dari masing-masing saham portofolio optimal dengan model Markowitz pada perusahaan sektor pertambangan yang terdaftar di Bursa Efek Indonesia periode Januari 2019-Desember 2020?
3. Berapakah tingkat expected return dan tingkat risiko dari kombinasi portofolio optimal dengan model Markowitz pada perusahaan sektor pertambangan yang terdaftar di Bursa Efek Indonesia periode Januari 2019-Desember 2020?

\section{METODOLOGI PENELITIAN}

\subsection{Saham}

Saham adalah tanda pemilikan seseorang atau badan dalam suatu perusahaan atau perseroan terbatas. Saham berwujud selembar kertas yang menerangkan bahwa pemilik kertas merupakan pemilik perusahaan yang menerbitkan surat berharga tersebut. Porsi kepemilikan ditentukan oleh seberapa besar penyertaan yang ditanamkan dalam suatu perusahaan (Darmaji dan Fakhrudin, 2006).

\subsection{Portofolio}

Menurut Hadi (2013:207) portofolio adalah kumpulan suatu instrumen investasi yang dibentuk untuk memenuhi suatu sasaran umum investasi. Sasaran dari suatu portofolio investasi tentunya sangat tergantung dari individu masing-masing investor.Dalam membuat keputusan investasi biasanya investor yang rasional akan memilih portofolio yang optimal, karena selalu menginginkan tingkat return yang maksimal dari investasinya.

\subsection{Portofolio Optimal}

Portofolio optimal merupakan portofolio yang dibentuk dengan return harapan dan risiko yang terbaik. Pembentukan portofolio optimal dapat dilakukan dengan cara Model Markowitz(Hartono,2014:367).Dengan menggunakan model Markowitz juga memberikan hasil cukup efisien karena memiliki nilai return ekspektasi positif dari portofolio masing-masing. Faktor penentu dalam memilih anggota portofolio optimal terletak pada hasil bobot/proporsi untuk saham masing-masing. Adapun langkahlangkah yang dilakukan dalam menentukan portofolio optimal, sebagai berikut : 
1. Menghitung Return Masing-masing Saham Setiap Bulan

Menurut Jogiyanto (2015:265)return saham merupakan tingkat pengembalian yang diperoleh dari sejumlah investasi pada saham dan dapat dihitung dengan rumus :

$$
R i=\frac{\mathrm{Pt}-\mathrm{Pt}-1}{P t-1}
$$

(Sumber:Jogiyanto, 2015:265)

\section{Keterangan :}

$\mathrm{Ri} \quad=$ Return dari saham $\mathrm{i}$

$\mathrm{Pt}=$ Harga pada periode sekarang

$\mathrm{Pt}-1=$ Harga pada periode sebelumnya

2. Menghitung Expected Return dari Masing-masing Saham Perusahaan

Expected Return adalah return yang diharapkan olehinvestor akan dapat dihasilkan oleh investasi yang dilakukannya, dan dapat dihitung dengan rumus:

$$
E R i=\frac{\sum R t(i)}{n}
$$

(Sumber: Jogiyanto, 2015:281)

\section{Keterangan:}

$\mathrm{E}(\mathrm{Ri})=$ Expected Return

Rt(i) = Return saham i

$\mathrm{n} \quad=$ Jumlah periode

3. Menghitung Standar Deviasi (Risiko)

Saham Dari Masing-Masing Saham

Perusahaan yang Memilik Expected

Return Positif

Risiko saham dapat dihitung dengan menggunakan standar deviasi yang dapat dihitung dengan persamaan sebagai berikut:

$$
\mathrm{SD}=\sqrt{\frac{\sum_{i=1}^{n}\left|R_{i t}-E\left(R_{i}\right)\right|^{2}}{n-1}}
$$

(Sumber: Jogiyanto, 2015:287)

\section{Keterangan:}

$\mathrm{SD}=$ Standar deviasi

$\mathrm{R}_{\mathrm{it}} \quad=$ Nilai saham ke-i

$E\left(R_{i}\right)=$ Nilai expected return saham ke-i

$\mathrm{n} \quad=$ Jumlah dari observasi data historis untuk sampel besar dengan $n$ (paling sedikit 30 observasi) dan untuk sampel kecil menggunakan (n-1)

4. Menghitung Kovarian Antar Saham Dari Masing-Masing Perusahaan

Kovarian merupakan suatu ukuran absolut yang menunjukkan sejauh mana return dari dua sekuritas dalam portofolio cenderung untuk bergerak secara bersamasama.Nilai Kovarian saham dapat dihitung dengan persamaan berikut :

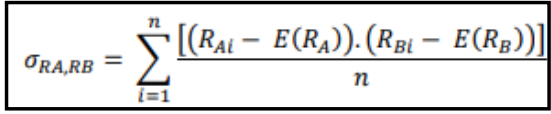

(Sumber: Jogiyanto, 2015:320)

\section{Keterangan:}

$\sigma_{\mathrm{RA}, \mathrm{RB}}=$ Kovarian returnantara saham A dan saham B

$\mathrm{R}_{\mathrm{Ai}} \quad=$ Return saham $\mathrm{A}$ pada periode $\mathrm{t}$

$\mathrm{R}_{\mathrm{Bi}}=$ Return saham $\mathrm{B}$ pada periode $\mathrm{t}$

$\mathrm{E}\left(\mathrm{R}_{\mathrm{A}}\right)=$ Expected return saham $\mathrm{A}$

$\mathrm{E}\left(\mathrm{R}_{\mathrm{B}}\right)=$ Expected return saham $\mathrm{B}$

$\mathrm{n} \quad=$ Jumlah observasi data historis untuk sampel besar (minimal30 observasi) dan untuk sampel kecil digunakan (n-1)

5. Menghitung Koefisien Korelasi Antar Saham Dari Masing-Masing Perusahaan

Koefisien korelasi merupakan ukuran statistik yang menunjukan pergerakan bersamaan relatif antara dua variabel, menjelaskan sejauh mana return dari suatu sekuritas terkait satu dengan lainnya.Nilai koefisien korelasi dapatdihitung dengan persamaan berikut:

(Sumber: Jogiyanto, 2015:322)

$$
r_{i, j}=\frac{\sum_{i j=1}^{n}\left(R_{i t}-R_{j t}\right)-n \cdot E\left(R_{i}\right) \cdot E\left(R_{j}\right)}{\sqrt{\left[\sum_{i, j=1}^{n} R_{i t}{ }^{2}-n \cdot E\left(R_{i}\right)^{2}\right]\left[\sum_{b=1}^{n} R_{j t}{ }^{2}-n \cdot E\left(R_{j}\right)^{2}\right]}}
$$

\section{Keterangan :}

ri, $\mathrm{j}=$ Koefisien Korelasi return saham $\mathrm{i}$ dan $\mathrm{j}$

Rit $=$ Return Saham i pada Periode $\mathrm{t}$

Rjt $\quad=$ Return Saham $\mathrm{j}$ pada Periode $\mathrm{t}$

$\mathrm{E}(\mathrm{Ri})=$ Return harapan $\mathrm{i}$

$E(R j)=$ Return harapan $\mathrm{j}$

$\mathrm{n} \quad=$ Banyaknya Periode Pengamatan 
6. Menghitung Expected Return Dan Risiko Portofolio Pada Proporsi Yang Sama

Return harapan dari portofolio adalah rata-rata tertimbang dari return harapan setiap saham yang masuk ke dalam portofolio dengan satuan persentase. Dimana expected return portofolio dihitung dengan mengkumulasi hasil perkalian dari expected return saham individual dengan proporsi saham individual. Expected Return portofoliodapat dihitung dengan persamaan sebagai berikut:

$$
E\left(R_{p}\right)=\sum_{a=1}^{n} W_{i} E\left(R_{i}\right)
$$

(Sumber: Jogiyanto, 2014:312)

\section{Keterangan :}

$\mathrm{E}\left(\mathrm{R}_{\mathrm{p}}\right)=$ Expected return portofolio

$\mathrm{E}\left(\mathrm{R}_{\mathrm{i}}\right)=$ Expected return saham $\mathrm{i}$

$\mathrm{W}_{\mathrm{i}} \quad=$ Bobot atau porsi dana yang dinvestasikan pada saham i

$\mathrm{n} \quad=$ Jumlah saham pada portofolio

7. Menghitung Expected Return Dan Risiko Portofolio Yang Optimal Dengan Memnimumkan Nilai Varians, Dan Memakai Fungsi Objektif

Langkah yang terakhir ini adalah, menghitung nilai return dan standar deviasi portofolio optimal yang dapat dibentuk yaitu nilai yang meminimumkan varians, dengan fungsi obyektif :

a. Total bobot adalah $100 \%$ [w1 + w2 $+\ldots . .+$ wn $=100 \%]$

b. Bobot-bobot setiap saham, lebih atau sama dengan nol $[\mathrm{w} 1 \geq 0, \mathrm{w} 2 \geq 0 \ldots$, wn $\geq 0]$ )

Setelah mendapatkan standar deviasi dan proporsi masing-masing saham maka akan terbentuk saham yang menjadi portofolio optimal yang ditunjukan ketika mencari proporsi dana yang optimal.

\section{METODE PENELITIAN \\ 3.1 Locus Penelitian}

Adapun Locus Penelitian ini adalah perusahaan sektor pertambangan yang terdaftar di Bursa Efek Indonesia periode Januari 2019-Desember 2020.

\subsection{Objek Penelitian}

Adapun Objek Penelitian ini adalah portofolio saham perusahaan sektor pertambangan yang terdaftar di Bursa Efek Indonesia periode Januari 2019-Desember 2020.

\subsection{Metode Penelitian}

Metode yang digunakan dalam penelitian ini adalah metode penelitian deskriptif kualitatif, yaitu suatu metode yang dimulai dengan cara mengumpulkan data, mencatat data, mengklasifikasikan data dan menganalisis data berdasarkan permasalahan yang telah dirumuskan dan kemudian menarik kesimpulan (Sugiyono, 2016:8).

\subsection{Metode Analisis Data}

Metode analisis yang digunakan dalam penelitian ini adalah analisis kuantitatifyang artinya analisis yang berlandaskan pada filsafat positivisme, digunakan untuk meneliti pada populasi dan sampel tertentu, pengumpulan data menggunakan instrumen penelitian, analisis data bersifat kuantitatif/statistik, dengan tujuan untuk menguji hipotesis yang telah ditetapkan (Sugiyono, 2014:13).

a. Untuk menjawab perumusan masalah pertama langkah-langkah yang harus dilakukan adalah sebagai berikut :

1. Menghitung Return Masing-masing Saham Setiap Bulan

2. Menghitung Expected Return dari Masing-masing Saham Perusahaan

3. Menghitung Standar Deviasi (Risiko) Saham Dari MasingMasing Saham Perusahaan yang Memilik Expected Return Positif

4. Menghitung Kovarian Antar Saham Dari Masing-Masing Perusahaan 
5. Menghitung Koefisien Korelasi Antar Saham Dari Masing-Masing Perusahaan

b. Untuk menjawab perumusan masalah kedua langkah-langkah yang harus dilakukan adalah sebagai berikut :

Dalam menentukan proporsi dana portofolio optimal pada setiap perusahaan sektor pertambangan yang terdaftar di Bursa Efek Indonesia periode Januari 2019Desember 2020 dapat menggunakan Aplikasi Program Solver di Microsoft Excel.

c. Untuk menjawab perumusan masalah ketiga langkah-langkah yang harus dilakukan adalah sebagai berikut :

1. Menentukan besar proporsi danayang akan dikeluarkan untuk kebutuhan investasi.

2. Menghitung Expected Return dari portofolio optimal.

3. Menghitung risiko (varians dan standar deviasi) dari portofolio.

Setelah mendapatkan standar deviasi dan proporsi masing-masing saham maka akan terbentuk saham yang menjadi portofolio optimal yang ditunjukan ketika mencari proporsi dana yang optimal.

\section{HASIL DAN PEMBAHASAN}

Dalam penelitian ini, locus penelitian yang dipilih adalah perusahaan sektor pertambangan yang terdaftar di Bursa Efek Indonesia periode Januari 2019 - Desember 2020. Dari populasi 47 perusahaan, didapatlah 11 perusahaan sektor pertambangan yang terdaftar di Bursa Efek Indonesia yang memenuhi kriteria sebagai sampel penelitian dengan metode purposive sampling yaitu pemilihan sampel perusahaan selama periode penelitian berdasarkan kriteria tertentu. Kriteriakriteria tersebut sebagai berikut:

- Perusahaan sektor pertambangan yang terdaftar di Bursa Efek Indonesia periode Januari 2019-Desember 2020.

- Perusahaan yang listing disektor pertambangan selama periode penelitian.
- Perusahaan yang mempublikasikan laporan keuangan secara konsisten dan lengkap selama periode Januari 2019Desember 2020.

- Perusahaan dalam menyajikan laporan keuangan menggunakan satuan mata uang rupiah.

\section{Menghitung Return Masing-masing Saham Setiap Bulan}

Tahap pertama dalam proses optimasi portofolio adalah menghitung return saham bulanan masing-masing perusahaan sampel penelitian yang dapat dihitung dengan rumus berikut:

$$
R i=\frac{\mathrm{Pt}-\mathrm{Pt}-1}{\mathrm{Pt}-1}
$$

(Sumber:Jogiyanto, 2015:265)

\section{Menghitung Expected Return dari Masing-masing Saham Perusahaan}

Tahap kedua dalam proses optimasi portofolio adalah menghitung expected return saham masing-masing perusahaan sampel penelitian. Perhitungan ini memiliki faktor yang cukup berpengaruh dalan penentuan setiap saham yang layak masuk ke dalam portofolio optimal. Expected Return dapat dihitung dengan rumus berikut:

$$
E(R i)=\frac{\sum R t(i)}{n}
$$

(Sumber: Jogiyanto, 2015:281)

Expected return saham masing-masing perusahaan yang dijadikan sampel dapat dilihat pada tabel 1 berikut: 
Tabel 1

Expected Return Masing-masing Saham Perusahaan

\begin{tabular}{|c|c|c|c|c|}
\hline No & Kode Saham & $\frac{\sum \boldsymbol{R t}(\boldsymbol{i})}{\boldsymbol{n}}$ & $\mathbf{E}\left(\mathbf{R}_{\mathbf{i}}\right)$ & $\mathbf{E}\left(\mathbf{R}_{\mathbf{i}}\right)(\boldsymbol{\%})$ \\
\hline 1 & ADRO & 0,320099 & 0,013337 & 1,33 \\
\hline 2 & HRUM & 0,960205 & 0,040009 & 4,00 \\
\hline 3 & ANTM & 1,416233 & 0,05901 & 5,90 \\
\hline 4 & TINS & 1,211065 & 0,050461 & 5,04 \\
\hline 5 & ITMG & $-0,03519$ & $-0,00147$ & $-0,14$ \\
\hline 6 & PTBA & $-0,30452$ & $-0,01269$ & $-1,26$ \\
\hline 7 & PTRO & 0,26662 & 0,011109 & 1,11 \\
\hline 8 & SURE & $-0,13696$ & $-0,00571$ & $-0,57$ \\
\hline 9 & BYAN & $-0,17679$ & $-0,00737$ & $-0,73$ \\
\hline 10 & MDKA & 1,442787 & 0,060116 & 6,01 \\
\hline 11 & INDY & 0,613363 & 0,025557 & 2,55 \\
\hline
\end{tabular}

Sumber : www.yahoo.finance.com (data diolah, 2021)

Berdasarkan Tabel 1 diatas nilai expected return diperoleh dengan membagi total return masing-masing perusahaan dengann atau jumlah periode. Dengan demikian diantara 11 (sebelas) saham tersebut yang akan menjadi kandidat dalam pembentukan portofolio optimal ada 7 (tujuh) buah saham yaitu ADRO, HRUM, ANTM, TINS, PTRO, MDKA dan INDY karena ketujuh buah saham tersebut memiliki expected return yang positif.

\section{Menghitung Standar Deviasi (Risiko) Saham Dari Masing-Masing Saham Perusahaan yang Memilik Expected Return Positif}

Tahap ketiga dalam proses optimasi portofolio adalah menghitung standar deviasi. Hasil perhitungan standar deviasi saham masing-masing perusahaan yang dijadikan sampel dihitung dari expected return yang bernilai positif dan dapat dilihat di tabel berikut:

Tabel 2

Standar Deviasi Masing-masing Saham Perusahaan yang Memiliki Expected Return Positif

\begin{tabular}{|c|c|c|c|c|c|c|}
\hline No & $\begin{array}{c}\text { Kode } \\
\text { Saham }\end{array}$ & $\sum \boldsymbol{R}_{i t}$ & $\mathbf{E}\left(\mathbf{R}_{\mathbf{i}}\right)$ & $\sum \boldsymbol{R}_{\boldsymbol{i t}} \mathbf{E}\left(\mathbf{R}_{\mathbf{i}}\right)$ & $\left(\sum \boldsymbol{R}_{i t} \mathbf{E}\left(\mathbf{R}_{\mathbf{i}}\right)\right)^{\mathbf{2}}$ & $\sqrt{\frac{\left(\sum \boldsymbol{R i t}-\mathbf{E}(\mathbf{R i})\right) \mathbf{2}}{\boldsymbol{n}-\mathbf{1}}}$ \\
\hline 1 & ADRO & 0,320099 & 0,013337 & 0,306762 & 0,094103 & 0,125235 \\
\hline 2 & HRUM & 0,960205 & 0,040009 & 0,920196 & 0,846760 & 0,375668 \\
\hline 3 & ANTM & 1,416233 & 0,05901 & 1,357223 & 1,842054 & 0,554083 \\
\hline 4 & TINS & 1,211065 & 0,050461 & 1,160604 & 1,347001 & 0,473814 \\
\hline 5 & PTRO & 0,26662 & 0,011109 & 0,255511 & 0,065285 & 0,104311 \\
\hline 6 & MDKA & 1,442787 & 0,060116 & 1,382671 & 1,911780 & 0,564461 \\
\hline 7 & INDY & 0,613363 & 0,025557 & 0,587806 & 0,345516 & 0,758854 \\
\hline
\end{tabular}

Sumber : www.yahoo.finance.com (data diolah, 2021)

Menghitung Kovarian Antar Saham Dari Masing-Masing Perusahaan

Tahap keempat dalam proses optimasi portofolio adalah menghitung kovarian antar saham masing-masing perusahaan sampel penelitian.

Hasil perhitungan kovarian antar saham dapat dilihat pada tabel berikut ini: 
Tabel 3

Kovarian Antar Saham Pada Perusahaan Sektor Pertambangan yang Terdaftar Di Bursa Efek Indonesia Periode Januari 2019-Desember 2020

\begin{tabular}{|c|c|l|l|l|l|l|c|}
\hline & ADRO & \multicolumn{1}{|c|}{ HRUM } & \multicolumn{1}{|c|}{ ANTM } & \multicolumn{1}{|c|}{ TINS } & \multicolumn{1}{c|}{ PTRO } & MDKA & INDY \\
\hline ADRO & 0,014091 & 0,003364 & 0,005625 & 0,011216 & 0,0058319 & $-0,00019$ & 0,014727 \\
\hline HRUM & 0,003364 & 0,018733 & 0,011902 & 0,012289 & 0,0018496 & $-0,00181$ & 0,014134 \\
\hline ANTM & 0,005625 & 0,011902 & 0,047682 & 0,035739 & 0,0097006 & 0,01476 & 0,018655 \\
\hline TINS & 0,011216 & 0,012289 & 0,035739 & 0,052641 & 0,0173205 & 0,00988 & 0,034603 \\
\hline PTRO & 0,005832 & 0,00185 & 0,009701 & 0,017321 & 0,0185883 & 0,006443 & 0,022573 \\
\hline MDKA & $-0,00019$ & $-0,00181$ & 0,01476 & 0,00988 & 0,0064431 & 0,015026 & 0,006897 \\
\hline INDY & 0,014727 & 0,014134 & 0,018655 & 0,034603 & 0,0225732 & 0,006897 & 0,05741 \\
\hline
\end{tabular}

Sumber : www.yahoo.finance.com (data diolah, 2021)

Menghitung Koefisien Korelasi Antar Saham Dari Masing-Masing Perusahaan

Tahap kelima dalam proses optimasi portofolio adalah menghitung korelasi antar saham masing-masing perusahaan sampel penelitian.

Hasil perhitungan korelasi antar saham dapat dilihat pada tabel berikut ini:

Tabel 4

Korelasi Antar Saham Pada Perusahaan Sektor Pertambangan yang Terdaftar Di Bursa Efek Indonesia Periode Januari 2019-Desember 2020

\begin{tabular}{|c|l|l|l|l|l|l|c|}
\hline & ADRO & HRUM & \multicolumn{1}{|c|}{ ANTM } & \multicolumn{1}{|c|}{ TINS } & \multicolumn{1}{|c|}{ PTRO } & MDKA & INDY \\
\hline ADRO & 1 & 0,216042 & 0,22646 & 0,429742 & 0,37602 & $-0,01363$ & 0,540322 \\
\hline HRUM & 0,216042 & 1 & 0,41554 & 0,408343 & 0,103425 & $-0,11226$ & 0,449733 \\
\hline ANTM & 0,22646 & 0,41554 & 1 & 0,74437 & 0,340004 & 0,575386 & 0,372048 \\
\hline TINS & 0,429742 & 0,408343 & 0,74437 & 1 & 0,577778 & 0,366552 & 0,656815 \\
\hline PTRO & 0,37602 & 0,103425 & 0,340004 & 0,577778 & 1 & 0,402286 & 0,721044 \\
\hline MDKA & $-0,01363$ & $-0,11226$ & 0,575386 & 0,366552 & 0,402286 & 1 & $-0,24503$ \\
\hline INDY & 0,540322 & 0,449733 & 0,372048 & 0,656815 & 0,721044 & 0,24509 & 1 \\
\hline
\end{tabular}

Sumber : www.yahoo.finance.com (data diolah, 2021)

Menghitung Expected Return Dan Risiko Portofolio Pada Proporsi Dana Yang Sama

Tahap keenam dalam proses optimasi portofolio adalah menghitung expected return dan risiko portofolio pada proporsi yang sama untuk setiap saham. Proporsi dana pada awal portofolio menggunakan asumsi bahwa seluruh dana yang dinvestasikan dibagi secara proporsional
(100\% dibagi $\mathrm{n}$ saham) untuk masingmasing saham, sehingga setiap saham mendapat proporsi dana sebesar 14,28\%.

Hasil perhiungan expected return dan risiko portofolio dengan proporsi saham yang sama dapat dilihat pada Tabel 5 berikut: 
Tabel 5

Expected Return dan Risiko Portofolio dengan Proporsi Dana yang Sama

\begin{tabular}{|c|c|c|}
\hline No & Kode Saham & Proporsi Dana \\
\hline 1 & ADRO & $14,28 \%$ \\
\hline 2 & HRUM & $14,28 \%$ \\
\hline 3 & ANTM & $14,28 \%$ \\
\hline 4 & TINS & $14,28 \%$ \\
\hline 5 & PTRO & $14,28 \%$ \\
\hline 6 & MDKA & $14,28 \%$ \\
\hline 7 & INDY & $14,28 \%$ \\
\hline \multicolumn{2}{|c|}{ Total Proporsi Dana } & $100 \%$ \\
\hline & Expected Return & $3,70 \%$ \\
\hline & Standar Deviasi & $5,11 \%$ \\
\hline
\end{tabular}

Sumber : www.yahoo.finance.com (data diolah, 2021)

\section{Menghitung Expected Return Dan Risiko Portofolio dengan Proporsi yang Optimal}

Tahap ketujuh dalam proses optimasi portofolio adalah menghitung expected return dan risiko portofolio dengan proporsi saham yang optimal. Dengan bantuan program Solver dalam Microsoft Excel, optimasi portofolio dapat dilakukan dengan meminimumkan risiko portofolio dengan salah satu fungsi formula yang digunakan adalah $\quad=($ MMULT $($ MINVERSE (VarianKovarian),TRANSPOSE(Satu)))/C C). Perhitungan dengan program ini akan menunjukkan proporsi dana akhir yang layak dialokasikan atau diinvestasikan pada masing-masing saham. Hasil perhitungan akhir ini dapat dilihat pada Tabel 6 berikut ini:

Tabel 6

\section{Expected Return dan Risiko Portofolio dengan Proporsi yang Optimal}

\begin{tabular}{|c|c|c|}
\hline No & Kode Saham & Proporsi Dana \\
\hline 1 & ADRO & $0,00 \%$ \\
\hline 2 & HRUM & $12,45 \%$ \\
\hline 3 & ANTM & $0,00 \%$ \\
\hline 4 & TINS & $24,42 \%$ \\
\hline 5 & PTRO & $0,00 \%$ \\
\hline 6 & MDKA & $53,07 \%$ \\
\hline 7 & INDY & $10,05 \%$ \\
\hline & Expected Return & $4,70 \%$ \\
\cline { 2 - 3 } & Standar Deviasi & $2,83 \%$ \\
\hline
\end{tabular}

Sumber: $\underline{w w w . y a h o o . f i n a n c e . c o m}$ (data diolah, 2021)

Berdasarkan Tabel 6 diatas, proporsi dana yang optimal pada masing-masing saham memberikan expected return sebesar $4,70 \%$ dan standar deviasi sebesar $2,83 \%$. 
Analisis perhitungan dalam menentukan proporsi dana optimal yang telah dilakukan dengan menggunakan Aplikasi Program Solver di Ms.Excel memberikan hasil bahwa pembentukan portofolio optimal menggunakan model Markowitz ini memperoleh 4 saham yang menjadi portofolio optimal yang terdiri dari PT. Harum Energy Tbk (HRUM) sebesar 12,45\%, PT. Timah Tbk (TINS) sebesar 24,42\%, PT. Merdeka Copper Gold Tbk (MDKA) sebesar 53,07\% dan yang terakhir PT. Indika Energy Tbk (INDY) sebesar $10,05 \%$. Sedangkan 3 saham lainnya yang tidak termasuk dalam portofolio optimal adalah PT. Adaro Energy Tbk (ADRO), PT. Aneka Tambang Tbk (ANTM) dan PT. Petrosea Tbk (PTRO) karena nilai proporsi dananya menjadi $0,00 \%$ setelah di optimalkan.

Perbedaan investasi antara portofolio dengan proporsi dana yang sama dan portofolio dengan proporsi dana yang optimal sudah sangat jelas terlihat dari expected return maupun tingkat risikonya (standar deviasi). Portofolio dengan proporsi dana yang sama memberikan expected return sebesar 3,70\% sedangkan pada proporsi dana yang optimal nilai expected return sebesar $4,70 \%$. Lalu tingkat risiko proporsi dana yang sama sebesar $5,11 \%$ dan sedangkan tingkat risiko pada proporsi dana yang optimal sebesar $2,83 \%$. Sehingga tingkat risiko risiko antara proporsi dana yang sama dengan proporsi dana yang optimal yang ditanggung investor memiliki selisih sebesar 2,28\% (menurun) bila menggunakan model markowitz dalam pembentukan portofolio optimal. Hasil penelitian ini membuktikan bahwa pembentukan portofolio optimal dengan model Markowitz dapat memberikan tingkat risiko seminimal mungkin dengan keuntungan yang sama bahkan lebih besar daripada membentuk portofolio tanpa menentukan bobot yang layak untuk diinvestasikan. Portofolio dengan model Markowitz ini sangat cocok untuk investor yang tidak menyukai risiko (risk averter). Hasil penelitian ini sejalan dengan penelitian sebelumnya yang dilakukan oleh Mahayani dan Suarjaya (2019)yang menunjukkan diversifikasi Markowitz terbukti dapat mengurangi risiko dalam suatu investasi.

\section{KESIMPULAN DAN SARAN \\ 5.1 Kesimpulan}

Berdasarkan hasil analisis data dan pembahasan yang telah dilakukan, maka diperoleh kesimpulan sebagai berikut:

1. Locus dalam penelitian ini merupakan perusahaan sektor pertambangan yang terdaftar di Bursa Efek Indonesia periode Januari 2019-Desember 2020 yang berjumlah 11 perusahaan yakni PT Adaro Energy Tbk (ADRO), PT Harum Energy Tbk (HRUM), PT Aneka Tambang Tbk (ANTM), PT Timah Tbk (TINS), PT Indo Tambangraya Megah Tbk (ITMG), PT Bukit Asam Tbk (PTBA), PT Petrosea Tbk (PTRO), PT Super Energy Tbk (SURE), PT Bayan Resources Tbk (BYAN), PT Merdeka Copper Gold Tbk (MDKA) dan PT. Indika Energy Tbk (INDY). Lalu setelah dilakukan analisis ada 7 perusahaan yang menjadi kandidat portofolio optimal karena memiliki nilai expected return yang positif yakni PT Adaro Energy Tbk (ADRO), PT Harum Energy Tbk (HRUM), PT Aneka Tambang Tbk (ANTM), PT Timah Tbk (TINS), PT Petrosea Tbk (PTRO), PT Merdeka Copper Gold Tbk (MDKA) dan PT. Indika Energy Tbk (INDY).

2. Proporsi dana dari masing-masing saham portofolio optimal adalah 4 saham yang menjadi portofolio optimal yang terdiri dari PT. Harum Energy Tbk (HRUM) sebesar 12,45\%, PT. Timah Tbk (TINS) sebesar 24,42\%, PT. Merdeka Copper Gold Tbk (MDKA) sebesar 53,07\% dan yang terakhir PT. Indika Energy Tbk (INDY) sebesar 10,05\%.

3. Tingkat expected return dan tingkat risiko dari kombinasi portofolio optimal yakni pada portofolio dengan 
proporsi dana yang sama memberikan expected return sebesar 3,70\% sedangkan pada proporsi dana yang optimal nilai expected return sebesar $4,70 \%$. Lalu tingkat risiko proporsi dana yang sama sebesar $5,11 \%$ dan sedangkan tingkat risiko pada proporsi dana yang optimal sebesar $2,83 \%$.

4. Tingkat risiko antara proporsi dana yang sama dengan proporsi dana yang optimal yang ditanggung investor memiliki selisih sebesar 2,28\% (menurun) bila menggunakan model markowitz dalam pembentukan portofolio optimal. Hal ini membuktikan bahwa pembentukan portofolio optimal dengan model Markowitz dapat memberikan tingkat risiko seminimal mungkin dengan keuntungan yang sama bahkan lebih besar daripada membentuk portofolio tanpa menentukan bobot yang layak untuk diinvestasikan. Portofolio dengan model Markowitz ini sangat cocok untuk investor yang tidak menyukai risiko (risk averter).

\subsection{SARAN}

Dari hasil penelitian dan pembahasan yang telah dilakukan pada bab sebelumnya tentang analisis penentuan sahamportofolio optimal dengan model Markowitz, maka dapat disarankan:

1. Bagi Perusahaan

Perusahaan yang sahamnya tidak masuk dalam kandidat portofolio optimal, diharapkan dapat melakukan evaluasi kinerja saham (mengukur berdasarkan kinerja yang memperhitungkan risk dan reward) pada perusahaan tersebut. Sedangakan perusahaan yang sahamnya masuk dalam portofolio optimal diharapkan dapat mempertahankan dan meningkatkan lagi kinerja sahamnya agar terus konsisten masuk dalam kriteria portofolio saham yang optimal.
2. Bagi Investor

Investor yang ingin berinvestasi, khususnya investasi jangka panjang sebaiknya disarankan untuk menginvestasikan dananya sesuai dengan portofolio optimal yang terbentuk dengan besar proporsi yang telah ada dari saham-saham berikut ini, yang terdiri dari PT. Harum Energy Tbk (HRUM), PT. Timah Tbk (TINS), PT. Merdeka Copper Gold Tbk (MDKA) dan PT. Indika Energy Tbk (INDY).

3. Bagi Penelitian Selanjutnya

Peneliti selanjutnya diharapkan dapat melakukan analisis investasi saham dengan berbagai macam sektor dan sub-sektor perusahaan sehingga portofolio optimal terdiri dari banyak sektor yang lebih bervariasi. Serta peneliti selanjutnya bias juga menggunakan model indeks tunggal atau membandingkan portofolio optimal yang dibentuk berdasarkan model markowitz dan berdasarkan model indeks tunggal dalam menganalisis saham portofolio optimalnya.

\section{DAFTAR PUSTAKA}

Hadi, Nor. 2013. Pasar Modal: Acuan Teoritis dan Praktis Investasi di Instrumen Keuangan Pasar Modal. Edisi Pertama. Yogyakarta: Graha Ilmu.

Darmadji, Tjiptono dan Hendy M. Fakhruddin. 2012. Pasar Modal Di Indonesia: Pendekatan Tanya Jawab. Jakarta: Salemba Empat.

Hadi, Nor. 2013. Pasar Modal: Acuan Teoritis dan Praktis Investasi di Instrumen Keuangan Pasar Modal. Edisi Pertama. Yogyakarta: Graha Ilmu. 
Halim, Abdul. 2005. Analisis Investasi.Edisi Kedua. Jakarta: Salemba Empat.

Jogiyanto, Hartono. 2012. Teori Portofolio dan Analisis Investasi. Edisi Ketujuh. Yogyakarta: BPFE.

Hartono, Jogiyanto. 2017. Teori Portofolio dan Analisis Investasi. Edisi Kesebelas. Yogyakarta: BPFE.

Markowitz, Harry M. 1952. Portfolio Selection. Journal of Finance. 7(1), pp: 77-91.

Pracanda, Desak Gede Sinta Putri dan Nyoman Abudanti. 2017. Pembentukan Portofolio Optimal Dengan Menggunakan Model Markowitz Pada Saham Indeks Idx30 Di Bursa Efek Indonesia. Jurnal Manajemen Unud. Vol. 6, No. 2,

Sugiyono. 2013. Metode Penelitian Bisnis (Pendekatan Kuantitatif, Kualitatif, dan $R \& D)$. Bandung: Alfabeta.

Tandelilin, Eduardus. 2010. Portofolio dan Investasi Teori dan Aplikasi. Edisi Pertama. Yogyakarta: Kanisius.

www.idx.co.id.

$\underline{\text { www.yahoofinance.com }}$ 